JURNAL PENDIDIKAN, p-ISSN 2715-095X, e-ISSN 2686-5041

Volume 30, No.2, Juli 2021 (143-152)

Online: http://journal.univetbantara.ac.id/index.php/jp

\title{
Pengaruh Kompetensi dan Motivasi Kerja Terhadap Kinerja Guru di SMP Negeri 4 Kota Lubuklinggau Sumatera Selatan
}

\author{
Yohanes Susanto $^{1}$, Jefirstson Richset Riwukore ${ }^{2 *}$, Isti Afrianti ${ }^{1}$, Fellyanus Habaora ${ }^{2}$ \\ ${ }^{1}$ Universitas Bina Insan Lubuklinggau, Jl. Jenderal Besar Moh. Soeharto, Lubuk Kupang, Lubuk Linggau \\ Selatan I, Kota Lubuk Linggau, Sumatera Selatan, 36125 \\ ${ }^{2}$ Universitas Indo Global Mandiri, Jl. Jenderal Sudirman, KM-4, No.629, Palembang, Sumatera Selatan, \\ 30129 \\ Alamat korespondensi: jefritson@uigm.ac.id \\ *Corresponding Author
}

Received: Juni 02, 2021

Accepted: Juni 07, 2021

Online Published: Juni 26, 2021

\begin{abstract}
Abstrak: Tujuan penelitian untuk mengetahui besaran pengaruh kompetensi dan motivasi kerja terhadap kinerja guru di Sekolah Menengah Pertama Negeri 4 Kota Lubuklinggau. Penelitian ini menggunakan metode assosiatif kuantitatif, dengan menghubungkan variabel bebas dengan variabel terikat. Penelitian ini dilakukan dengan membagikan kuesioner kepada para guru dengan sampel sebanyak 45 responden. Teknis analisis pada peelitian ini menggunakan teknis statistik analisis regresi linier berganda dengan aplikasi SPSS 20.0. Hasil penelitian diperoleh bahwa berdasarkan nilai uji t-hitung untuk variabel kompetensi sebesar 2,722 > dari t-tabel 2,021 dengan nilai sig 0,000 . Hal ini menunjukan bahwa kompetensi berpengaruh terhadap kinerja guru, sedangkan untuk variabel motivasi uji t-hitung sebesar 3,022 > dari t-tabel 2,021 dengan nilai sig 0,000 yang berarti ada pengaruh seignifikan antara motivasi kerja terhadap kinerja guru. Berdasarkan hasil uji- $\mathrm{F}$ variabel kompetensi dan motivasi kerja guru sebesar $10,380>$ dari f-tabel 3,22 nilai sig 0,000 menunjukkan simultan variabel kompetensi dan motivasi secara bersama-sama berpengaruh positif dan signifikan terhadap kinerja guru di Sekolah Menengah Pertama Negeri 4 Kota Lubuklinggau, namun secara parsial motivasi kerja lebih dominan mempengaruhi kinerja guru, maka disarankan agar unsur pimpinan khususnya Kepala Sekolah agar dapat memberikan program kerja dan kesejahteraan guru guna memacu motivasi kerja di sekolah.
\end{abstract}

Kata-kata Kunci: kompetensi, motivasi kerja, dan kinerja guru

\section{The Influence of Competence and Work Motivation towards Teacher Performance in SMP Negeri 4 Kota Lubuklinggau Sumatera Selatan}

\author{
Yohanes Susanto $^{1}$, Jefirstson Richset Riwukore ${ }^{2 *}$, Isti Afrianti ${ }^{1}$, Fellyanus Habaora ${ }^{2}$ \\ ${ }^{1}$ Universitas Bina Insan Lubuklinggau, Jl. Jenderal Besar Moh. Soeharto, Lubuk Kupang, Lubuk Linggau \\ Selatan I, Kota Lubuk Linggau, Sumatera Selatan, 36125 \\ ${ }^{2}$ Universitas Indo Global Mandiri, Jl. Jenderal Sudirman, KM-4, No.629, Palembang, Sumatera Selatan, \\ 30129 \\ Alamat korespondensi:_efritson@uigm.ac.id
}

\begin{abstract}
The purpose of the study was to determine the magnitude of the effect of competence and work motivation on teacher performance at SMP 4 in Lubuklinggau City. This research used a quantitative associative method, by linking the independent variables with the dependent variable. This research was conducted by distributing questionnaires to teachers with a sample of 45 respondents. Technical analysis in this study uses statistical techniques of multiple linear
\end{abstract}


regression analysis with the application of SPSS 20.0. The results showed that based on the ttest value for the competency variable, amounted to 2.722> of the t-table 2.021 with a sig value of 0,000. This shows that competence affects teacher performance, while for the t-test motivation variable is 3,022> from t-table 2,021 with a sig value of 0,000 which means there is a significant influence between work motivation on teacher performance. Based on the results of the F-test the competence and work motivation variables of teachers are 10.380> from the $f$ table 3.22 the sig value of 0.000 shows that simultaneously the competency and motivation variables together have a positive and significant effect on teacher performance in SMP N 4 Kota Lubuklinggau, but partially work motivation is more dominantly influencing teacher performance, it is suggested that the leadership element especially the Principal in order to provide work programs and teacher welfare in order to spur work motivation at school.

Keywords: competence, work motivation, and teacher performance

\section{Pendahuluan}

Ilmu pengetahuan dan teknologi semakin berkembang seiring dengan peradaban manusia, dan berimplikasi pada kebiasaan manusia (life style) yang ditunjukkan melalui kinerja dari sumber daya manusia (SDM), seperti SDM di bidang pendidikan. Salah satu SDM bidang pendidikan adalah guru yang memiliki peran besar dalam mentrasfer ilmu pengetahuan dan teknologi kepada para siswa melalui kegiatan pembelajaran dan pengajaran (Riwukore \& Habaora, 2021). Marlina (2015) menyatakan bahwa pembelajaran dan pengajaran yang dilakukan guru (pendidik) akan efektif apabila guru mampu menyusun perencanaan sampai pada tingkatan manajemen dengan baik.

Berdasarkan uraian di atas, dapat disimpulkan bahwa guru merupakan aktor sentral dan strategis dalam sistem pendidikan, sehingga guru perlu ditingkatkan kualitasnya untuk menjamin adanya profesionalitas guru dalam melaksanakan mutu pembelajaran dan pengajaran (Riyadi \& Mulyaprada, 2017). Indikator untuk menilai profesionalitas guru tersebut dapat dinilai berdasarkan kinerja guru, yaitu terkait dengan pencapaian tujuan, prestasi kerja, dan produktivitas. Riwukore \& Habaora (2021) menyatakan bahwa kinerja guru sangat dipengaruhi oleh kompetensi dan motivasi. Kompetensi adalah kemampuan mengerjakan sesuatu berdasarkan profesionalisme karena berbasis keahlian, ketrampilan, dan pengetahuan dalam suatu bidang tertentu (Riwukore, et al., 2021a). Kompetensi ini akan semakin baik didayagunakan apabila memiliki motivasi individu yang tinggi karena berdampak pada usaha kerja keras dan semangat untuk bekerja sesuai standar dalam mencapai tujuan yang telah ditetapkan (Riwukore, 2010). Dengan demikian, kompetensi dan motivasi memiliki pengaruh terhadap peningkatan kinerja, khususnya di bidang pendidikan.

Salah satu lembaga yang melaksanakan fungsi di bidang pendidikan adalah Sekolah Menengah Pertama Negeri (SMP N) 4 Kota Lubuklinggau Sumatera Selatan. Hasil observasi awal di SMP N 4 Kota Lubuklinggau, ditemukan beberapa indikasi lemahnya kompetensi dan motivasi guru yang dapat mempengaruhi kinerja guru, diantaranya: kurang memahami materi pembelajaran, kurang percaya diri dalam mengajar, belum mampu menggunakan perangkat teknologi yang mendukung pengajaran seperti laptop atau komputer, motivasi individu untuk menyelesaikan tugas masih rendah, peran kepala sekolah sebagai motivator guru pun rendah, penghargaan terhadap prestasi guru rendah, dan lambatnya pemberian upah kerja guru, rendah dalam menstimulasi pengalaman belajar siswa berdasarkan hasil belajar yang diperoleh siswa untuk memperbaiki proses pembelajaran, dan kurang persiapan dan perencanaan guru untuk memulai pembelajaran. 
Indikator yang menjadi indikasi lemahnya kompetensi dan motivasi yang dimiliki guru disinyalir akan mempengaruhi kinerja guru.

Kinerja guru adalah kemampuan guru dalam melaksanakan tugas profesinya sebagai pengajar dan pembelajar di sekolah, dan bertanggungjawab terhadap pembimbingan peserta didik untuk memperoleh ilmu pengetahuan dan beretika (Hasbi \& Yusman, 2016). Defenisi ini mendukung pernyataan Aini (2019) bahwa kinerja adalah tingkat keberhasilan seseorang secara keseluruhan selama periode tertentu dalam melaksanakan tugas sesuai dengan standar hasil kerja, sasaran atau kriteria yang telah ditentukan terlebih dahulu dan telah disepakati bersama. Menurut Riwukore \& Habaora (2019), kinerja merupakan perilaku nyata yang ditampilkan melalui hasil prestasi kerja karyawan untuk mencapai tujuannya.

Kompetensi dan motivasi merupakan indikator yang mempengaruhi kinerja guru (Riwukore \& Habaora, 2021). Indikator kinerja guru yaitu tampilan kualitas atau performa yang menunjukkan adanya jumlah dan mutu kerja yang harus dihasilkan guru seperti pengetahuan dan ketrampilan, sistem penempatan dan unit variasi pengalaman, kemampuan praktis dan kualifikasi, hasil pekerjaan, dan pengembangan (Togatorop \& Heryanto, 2019). Indikator kompetensi ada pada setiap manusia atau kepribadian seseorang yang memprediksikan tingkah laku dan performa disetiap situasi dan tugas pekerjaan (job tasks). Indikator motivasi ada dalam setiap kompetensi yang dapat menyebabkan perubahan perilaku dalam mengaplikasikan kopetensi yang ada (Novauli, 2015; (Riwukore et al., 2021b).

Kompetensi dapat dipahami sebagai karakteristik personel yang menentukan sukses tidaknya seseorang dalam mengerjakan tugas tertentu (Riwukore, 2020). Afrilyan, et al. (2017) menjelaskan kompetensi sebagai kemampuan melaksanakan atau melakukan pekerjaan dan tugas yang dilandasi ketrampilan dan pengetahuan dan didukung sikap kerja yang dituntut oleh pekerjaan tersebut. Menurut Riwukore (2010), ada beberapa faktor yang mempengaruhi kompetensi seseorang, diantaranya: (1) keyakinan dan nilai-nilai terhadap diri atau ke orang lain yang sangat mempengaruhi perilaku, seperti jika orang percaya bahwa diri mereka tidak kreatif dan inovatif maka mereka tidak akan berusaha berpikir tentang cara yang baru atau berbeda dalam pekerjaan; (2) ketrampilan yang berperan dalam kompetesi, seperti berbicara di depan banyak orang adalah ketrampilan yang dipelajari, dipraktikkan, dan dapat diperbaiki, sama halnya juga pada ketrampilan menulis yang dapat diperbaiki dengan instruksi, praktek, dan umpan balik; (3) pengalaman dimana kompetensi memerlukan pengalaman untuk mengorganisir orang, komunikasi di depan kelompok, menyelesaikan masalah, dan lain sebagainya, seperti orang yang belum pernah berhubungan dengan organisasi besar dan kompleks tidak mungkin mengembangkan kecerdasan organisasional untuk memahami dinamika kekuasaan dan pengaruh dalam lingkungan tersebut; (4) karakteristik kepribadian yang tergolong sulit diubah, tetapi kepribadian dalam kenyataan dapat diubah sepanjang waktu tergantung respon dan interaksi terhadap kekuatan lingkungan sekitarnya; (5) motivasi sebagai faktor dalam kompetensi yang dapat berubah jika mendapat respon, apresiasi kerja, pengakuan dan perhatian individual dari orang yang setara rekan maupun pimpinan; (6) isu emosional yang dapat membatasi pengaruh kompetensi seperti takut membuat kesalahan, menjadi malu, merasa tidak disukai atau tidak menjadi bagian yang seluruhnya membatasi motivasi dan inisiatif; (7) kemampuan intelektual dimana kompetensi sangat dependen pada pemikiran kognitif seperti berpikir konseptual dan berpikir analitis yang dipengaruh pengalaman; (8) budaya organisasi yang mempengaruhi kompetensi sumber daya manusia 
seperti praktik rekruitmen dan seleksi, sistem penghargaan, praktik pengambilan keputusan, filosofi organisasi, kebiasaan dan prosedur, komitmen dalam pelatihan dan proses organisasi. Indikator kompetensi terdiri atas: (1) pengetahuan (knowledge) yaitu kesadaran bidang kognitif, (2) pemahaman (understanding) yaitu kedalaman kognitif dan efektifitas dari individu, (3) kemampuan ( $s k i l l$ ) yaitu sesuatu yang dimiliki individu dalam melakukan pekerjaan yang ditugaskan, (4) nilai (value) yaitu standar perilaku yang diyakini kebenarannya dan menyatu dalam psikologis orang, (5) sikap (attitude) yaitu perasaan (senang-tidak senang; suka - tidak suka) atau reaksi dan respon pada rangsangan terhadap lingkungan eksternal (Riwukore, 2020).

Motif adalah kebutuhan yang distimulasi dan berorientasi pada tujuan individu dalam mencapai rasa puas (Hartono, 2019). Motivasi adalah keinginan untuk bertindak baik atas injeksi dari luar atau karena ada kekuatan yang berbeda seperti mempengaruhi bawahan untuk termotivasi menyelesaikan pekerjaan sesuai kebutuhan organisasi (Wibowo et al., 2017). Riwukore et al. (2021a) menyatakan bahwa motivasi berorientasi pada cara mendorong gairah kerja bawahan agar bekerja keras menggunakan seluruh kemampuan dan ketrampilan yang dimiliki agar tercapai tujuan organisasi. Danila \& Riwukore (2019) menjelaskan faktor yang mempengaruhi motivasi adalah individu dan pekerjaan yang akan tampak dalam kemampuan, pengetahuan kerja, disposisi dan sifat, emosi, suasana hati, keyakinan, dan nilai-nilai profesi pekerjaan. Ruang lingkupnya terdiri dari lingkungan fisik, penyelesaian tugas, pendekatan organisasi pada rekognisi dan penghargaan, pengawasan dan coaching, dan budaya organisasi. selanjutnya, indikator dari motivasi terdiri atas: (1) psikologis, yaitu salah satu bidang ilmu pengetahuan dan terapa tentang perilaku, fungsi, mental, dan proses mental manusia secara ilmiah; (2) keamanan, yaitu kebebasan dari atau ketahanan terhadap potensi bahaya atau perubahan paksaan yang tidak diinginkan lainnya yang diakibatkan oleh orang lain seperti orang atau kelompok sosial, objek dan lembaga, ekosistem, entitas dan fenomena lainnya yang rentan terhadap perubahan yang tidak diinginkan oleh lingkungannya; (3) sosial, yaitu bagian yang tidak utuh dari sebuah hubungan manusia sehingga membutuhkan pemakluman atas hal-hal yang bersifat rapuh di dalamnya; (4) penghargaan, yaitu sesuatu yang diberikan pada perorangan atau kelompok jika melakukan suatu keuntungan di bidang tertentu; dan (5) aktualisasi diri, yaitu ketepatan seseorang di dalam menempatkan dirinya sesuai dengan kemampuan yang ada di dalam dirinya (Riwukore, 2020).

Daryanto (2014) menyatakan bahwa faktor-faktor yang mempengaruhi kinerja adalah kompensasi, jenjang karir, dan citra karyawan. Kompensasi adalah balas jasa yang diberikan organisasi kepada karyawan yang ditentukan besarannya berdasarkan aturan formal terhadap aturan organisasi seperti kenaikan gaji dan tunjangan lainnya. Jenjang karir adalah penghargaan yang diberikan organisasi kepada seseorang yang memiliki prestasi atau kinerja baik seperti peningkatan karir dalam bentuk kenaikan jabatan dan atau kenaikan pangkat. Citra karyawan adalah pandangan terhadap seseorang karena telah melakukan sesuatu seperti seseorang yang berkinerja baik akan diberikan penghargaan dan pujian dan menjadi suri teladan, dan sebaliknya, berkinerja buruk akan di sanksi dan dicemooh.

Berdasarkan uraian yang telah dijelaskan, makada dapat dibuat kKerangka pemikiran penelitian seperti yang tersaji pada Gambar 1 . 
Y.Susanto, JR.Riwukore, I.Afrianti, dan F.Habaora, Pengaruh Kompetensi dan....147

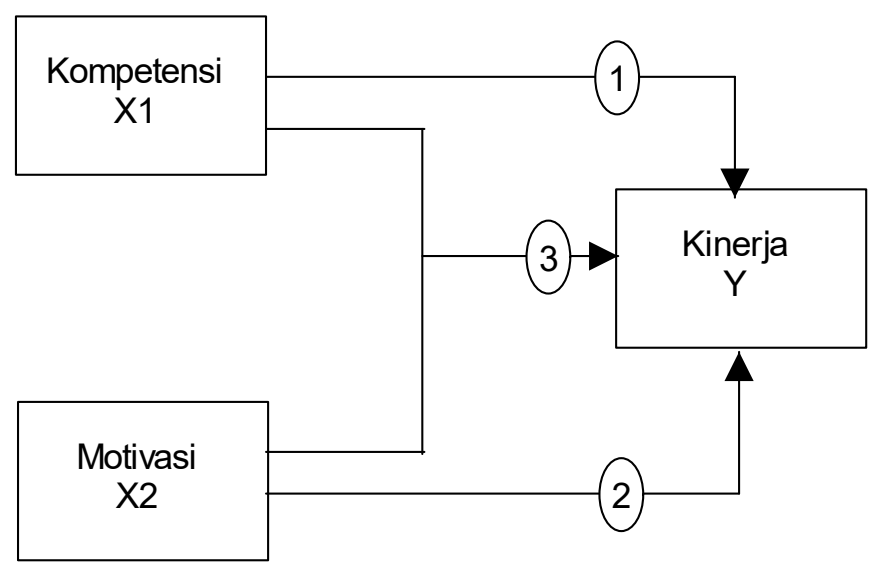

Gambar 1. Kerangka pemikiran penelitian

Berdasarkan kerangka penelitian maka dapat dikemukakan hipotesis penelitian, yaitu (1) kompetensi (X1) berpengaruh signifikan terhadap kinerja guru (Y); (2) motivasi kerja (X2) berpengaruh signifikan terhadap kinerja guru (Y), dan (3) kompetensi (X1) dan motivasi (X3) berpengaruh signifikan terhadap kinerja guru (Y).

\section{Metode Penelitian}

Penelitian ini dilaksanakan selama 7 bulan, yaitu mulai Juni-Desember 2021 di SMP Negeri 4 Kota Lubuklinggau Sumatera Selatan dengan pendekatan metode assosiatif kuantitatif yaitu menghubungkan variabel bebas dengan variabel terikat. Responden ditentukan menggunakan sampel jenuh yaitu sebanyak 45 sampel atau seluruh populasi dijadikan sebagai sampel penelitian. Populasi adalah wilayah generalisasi yang terdiri dari objek/subjek yang memiliki kualitas dan karakteristik tertentu yang ditentukan peneliti untuk dipelajari, kemudian diambil kesimpulannya. Populasi tidak hanya orang-orang, tetapi juga objek dan benda-benda alam lain. Populasi tidak hanya berorientasi jumlah pada objek/subjek yang dipelajari, tetapi meliputi seluruh karakteristik/sifat yang dimiliki oleh subjek atau objek itu. Sampel adalah bagian dari jumlah dan karakteristik yang dimiliki oleh populasi tersebut. Sampel jenuh adalah teknik penentuan sampel bila semua anggota populasi digunakan sebagai sampel (Sugiyono, 2017:119-120). Jenis data yang digunakan adalah data primer yang diperoleh dengan teknik observasi, kuisioner, dan dokumentasi (Sujarweni, 2014:75). Observasi adalah pengamatan dan pencatatan secara sistematik terhadap gejala yang tampak pada objek penelitian. Kuisioner merupakan teknik pengumpulan data yang dilakukan dengan cara menyebar seperangkat pertanyaan atau pernyataan tertulis kepada responden untuk dijawab. Dokumentasi adalah pengumpulan data yang berasal dari buku-buku, literatur ilmiah yang relevan, surat kabar, dan dokumen lainnya. Analisis data dilakukan secara linear berganda menggunakan aplikasi SPPS versi Windows 2.0.

\section{Hasil Penelitian}

Hasil uji regresi linier berganda menggunakan SPSS dalam penelitian ini dapat dilihat pada Tabel 1. 
Tabel 1. Uji regresi linear berganda

\begin{tabular}{|c|c|c|c|c|c|}
\hline \multicolumn{6}{|c|}{ Coefficients $^{\mathbf{a}}$} \\
\hline \multirow[t]{2}{*}{ Model } & \multicolumn{2}{|c|}{$\begin{array}{l}\text { Unstandardized } \\
\text { Coefficients }\end{array}$} & \multirow{2}{*}{$\begin{array}{c}\text { Standardized Coefficients } \\
\text { Beta }\end{array}$} & \multirow[t]{2}{*}{$\mathrm{t}$} & \multirow[t]{2}{*}{ Sig. } \\
\hline & B & Std. Error & & & \\
\hline (Constant) & 25.689 & 8.488 & & 3.027 & .004 \\
\hline 1 Kompetensi & .321 & .118 & .351 & 2.722 & .009 \\
\hline Motivasi Kerja & .280 & .093 & .390 & 3.022 & .004 \\
\hline a. Dependent Varia & e: Kine & Guru & & & \\
\hline
\end{tabular}

Sumber: Hasil primer diolah program SPSS 22 for windows, Tahun 2020

Berdasarkan data hasil olahan SPSS dapat diketahui hasil pengujian regresi linear berganda dalam persamaan $\mathrm{Y}=\mathrm{a}+\mathrm{b}_{1} \mathrm{X}_{1}+\mathrm{b}_{2} \mathrm{X}_{2}$, yaitu $\mathrm{Y}=25,689+0,321+0,28$. Berdasarkan persamaan yang telah ditulis tersebut, maka dapat dijelaskan bahwa (a) nilai konstanta yaitu sebesar 25,689. Hal ini menunjukan bahwa apabila variabel kompetensi dan motivasi kerja tidak mengalami perubahan atau nilai nol, maka nilai dari variabel kinerja guru adalah sebesar 25,689; (b) nilai koefisien regerasi variabel kompetensi sebesar 0,321 satuan. Hal ini menunjukan bahwa apabila nilai variabel kompetensi meningkat sebesar satu satuan, maka nilai variabel kompetensi akan mengalami perubahan secara positif sebesar 0,321 satuan. Sebaliknya, kinerja guru diprediksikan menurun jika kompetensi mengalami penurunan sebesar 0,321 satuan. Oleh karena itu dapat disimpulkan kompetensi mempunyai hubungan yang searah terhadap kinerja guru; (c) nilai koefisien regresi variabel motivasi kerja sebesar 0,280 satuan. Hal ini menunjukan bahwa apabila nilai variabel motivasi kerja meningkat sebesar satu satuan, maka nilai variabel motivasi kerja akan mengalami perubahan secara positif sebesar 0,280 satuan. Sebaliknya jika nilai regresi turun sebesar satu satuan, maka kinerja guru juga dipredisikan mengalami penurunan sebesar 0,280 satuan. Oleh karena itu dapat disimpulkan motivasi kerja mempunyai hubungan yang searah terhadap kinerja guru.

Tabel 2. Pengujian Terhadap Hipotesis

ANOVA ${ }^{b}$

\begin{tabular}{|c|c|c|c|c|c|}
\hline Model & Sum of Squares & $\mathrm{df}$ & Mean Square & $\mathrm{F}$ & Sig. \\
\hline 1 Regression & 285.994 & 2 & 142.997 & 10.380 & $.000^{\mathrm{a}}$ \\
\hline Residual & 578.583 & 42 & 13.776 & & \\
\hline Total & 864.578 & 44 & & & \\
\hline $\begin{array}{l}\text { a. Predictors: (C } \\
\text { b. Dependent V }\end{array}$ & $\begin{array}{l}\text { nstant), Motivasi } \\
\text { iable: Kinerja } \mathrm{Gu}\end{array}$ & & a, Kompetensi & & \\
\hline
\end{tabular}

Berdasarkan Tabel 2, dapat dilihat bahwa $F_{\text {hitung }}$ yang diperoleh adalah 10,380 $>3,22$ $\mathrm{F}_{\text {tabel }}=$ dan tingkat kemaknaan secara simultan signifikansinya adalah $0,000<(\alpha)=0,05 \mathrm{df}$ $=\mathrm{n}-\mathrm{k}=45-2-1=42$ adalah sebesar 3,22, sehingga $\mathrm{H} 0$ ditolak dan Ha diterima, artinya menunjukan bahwa secara bersama-sama (simultan) variabel bebas yaitu kompetensi dan motivasi kerja memiliki pengaruh yang signifikan terhadap variable terikat yaitu kinerja guru. Hasil penelitian ini membuktikan kebenaran dan hipotensisnya dapat diterima. 
Y.Susanto, JR.Riwukore, I.Afrianti, dan F.Habaora, Pengaruh Kompetensi dan....149

\section{Pembahasan}

\section{Pengaruh Parsial Kompetensi dan Motivasi Terhadap Kinerja Guru}

Hasil uji t pada Tabel 1 menunjukkan bahwa variabel kompetensi (X1) terhadap kinerja guru di SMP N 4 Kota Lubuklinggau menghasilkan nilai thitung 2,722 > nilai tabel 2,021 dengan signifikansi $0,000<\alpha 0.05 \mathrm{df}(\mathrm{n}-2) 45-2=43$ sebesar 2,021. Hasil penelitian ini menunjukkan hipotesis nol (H0) ditolak dan hipotesis alternatif (Ha) diterima, artinya secara parsial variabel kompetensi berpengaruh signifikan terhadap kinerja guru di SMP N 4 Kota Lubuklinggau. Adanya kompetensi yang dimiliki oleh para guru dapat lebih efektif dalam menyelesaikan tugas dengan penuh tanggungjawab sehingga hasil kerja yang dihasilkan baik (direction). Hasil penelitian sesuai yang dilaporan oleh Riwukore (2010), Novauli (2015), dan Riwukore \& Habaora (2021) bahwa kompetensi secara parsial memiliki pengaruh yang signifikan terhadap kinerja atau dengan kata lain kompetensi signifikan terhadap peningkatan produktivitas pelayanan maupun pekerjaan yang dilakukan oleh pegawai. Fathurrochman (2017) menyatakan bahwa adanya pengembangan kompetensi ASN pada dasarnya bertujuan untuk memastikan dan memelihara kemampuan pegawai sehingga memenuhi kualifikasi yang diprasyaratkan sehingga dapat memberi kontribusi optimal bagi organisasi. Salah satu sebab kinerja pegawai sering disorot dan kritik karena tidak memiliki kompetensi sehingga menunjukkan kinerja yang kurang produktif, hanya menghabiskan anggaran negara, kedisiplinan rendah, dan etos kerja yang rendah. Komara (2019) menjelaskan bahwa kompetensi pegawai dapat dipahami sebagai sebuah kombinasi antara ketrampilan, atribut personal, dan pengetahuan yang tercermin melalui perilaku kinerja yang dapat diamati, diukur, dan dievaluasi.

Selanjutnya, variabel motivasi (X1) terhadap kinerja guru (Y) berdasarkan hasil uji $\mathrm{t}$ pada Tabel 1 menunjukkan nilai $t_{\text {hitung }}=3,022>$ nilai $t_{\text {tabel }} 2,042$ dengan nilai signifikansi $0,000<\alpha 0.05$ dengan df (n-2) 31-2 = 29 adalah sebesar 2,042. Artinya hipotensis nol (H0) ditolak dan hipotesis alternatif (Ha) diterima. Dengan demikian secara parsial variabel motivasi memiliki pengaruh yang signifikan terhadap kinerja guru di SMP N 4 Kota Lubuklinggau. Adanya motivasi diharapkan guru lebih efektif dalam menyelesaikan tugas dari organisasi dengan keadaan yang menyenangkan. Hal ini sesuai yang dilaporkan oleh Riwukore (2010) bahwa salah satu faktor determinan keberhasilan organisasi adalah motivasi kerja. Meirina (2013) dan Santoso (2013) menyatakan indikasi kinerja pegawai dipengaruhi motivasi pegawai dalam melaksanakan profesinya. Habaora (2015) menyatakan bahwa individu dapat bekerja secara profesional jika didirinya terdapat motivasi yang tinggi, karena umumnya akan melaksanakan tugasnya dengan penuh semangat dan enerjik karena dipenuhi motif-motif atau tujuan tertentu yang melatarbelakangi tindakan tersebut. Habaora (2020) menyatakan bahwa motif tersebut menjadi faktor penggerak dan pendorong sebagai kekuatan untuk bekerja produktif. Wijaya (2015) menyatakan bahwa ada hubungan yang positif antara motivasi dengan pencapaian kerja sehingga individu yang mempunyai motivasi tinggi akan mencapai kerja yang produktif, dan sebaliknya mereka yang tidak produktif karena memiliki motivasi kerja yang rendah.

\section{Pengaruh Simultan Kompetensi dan Motivasi Terhadap Kinerja Guru}


Hasil analisis menggunakan SPSS pengaruh kompetensi dan motivasi secara bersama-sama terhadap kinerja guru sesuai informasi pada Tabel 2 menunjukkan bahwa nilai $F_{\text {hitung }} 10,380>$ nilai $F_{\text {tabel }} 3,22$ dengan signifikansi $0,000<\alpha 0,05$ (df $=n-k=45-2-$ $1=42$ ) adalah sebesar 3,22. Artinya, hipotesis nol (H0) ditolak dan hipotesis alternatif (Ha) diterima yang menjelaskan bahwa variabel bebas kompetensi dan motivasi secara bersamasama (simultan) memiliki pengaruh signifikan terhadap variabel terikat kinerja guru. Dengan demikian hasil penelitian ini terbukti nilai kebenarannya dna hipotesisnya dapat diterima. Hasil penelitian ini sesuai yang dilaporkan oleh Riwukore (2010) bahwa kompetensi dan motivasi secara simultan memiliki pengaruh yang positif dan signifikan terhadap kinerja pegawai.

Seorang guru memiliki peran sangat penting menggunakan kompetensinya untuk mengatur siswa dalam mencapai tujuan organisasinya, demikian juga dengan tindakan motivasi yang dilakukan atau diambil oleh guru pada akhirnya berpengaruh pada kinerja guru dalam melaksanakan tugas. Mahdane et al. (2018) menyatakan bahwa kinerja guru akan meningkatkan akibat pengaruh kompetensi karena kompetensi berorientasi pada aplikasi kemampuan yang dilandasi ketrampilan dan pengetahuan juga sikap kerja untuk melaksanakan tuntutan pekerjaan. Demikian juga dengan motivasi kerja sebagai daya penggerak yang menciptakan kegairahan seseorang untuk mau bekerjasama, bekerja efektif, dan terintegrasi dengan segala daya upaya untuk mencapai kepuasan. Hal ini seperti yang jelaskan Winbaktianur \& Putri (2017) bahwa motivasi kerja merupakan suatu modal dalam menggerakkan dan mengarahkan para pegawai atau pekerja untuk dapat melaksanakan tugasnya masing-masing dalam mencapai sasaran dengan penuh kesadaran, kegairahan, dan bertanggungjawab.

Guru di SMP N 4 Kota Lubuklinggau berkerja dengan menggunakan seluruh kemampuan kompetensi dan memacu motivasi untuk mencapai visi misi organisasi sehingga sangat diperlukan adanya manajemen yang baik. Meskipun demikian, tidak semua guru memiliki motivasi yang tinggi akibat keterikatan emosional, pengidentifikasian dan keterlibatan guru terhadap satu instansi, produtivitas dan semangat yang dapat mempengaruhi kinerja guru. Kompetensi guru dan pemberian motivasi untuk pencapaian kinerja guru ditentukan oleh kualitas manajer (kepala sekolah) yang baik. keberhasilannya, jika seorang guru memihak pada pekerjaan tersebut dengan sendirinya tujuan organisasi tercapai.

\section{Simpulan dan Saran}

Berdasarkan hasil penelitian dan pembahasan, maka dapat disimpulkan bahwa variabel kompetensi dan motivasi kerja terhadap kinerja guru di SMP Negeri 4 Kota Lubuklinggau memiliki pengaruh parsial dan simultan terhadap kinerja guru. Saran yang dapat diberikan dalam melaksanakan kompetensi dan motivasi kerja diharapkan guru dapat memahami materi pembelajaran dan memiliki keyakinan dalam diri sendiri untuk mampu mengajar dan mengoperasikan komputer, guru harus bisa memotivasi dirinya sendiri untuk menyelesaikan tugas yang diberikan, kepala sekolah berkewajiban memberikan apresiasi dan kesejahteraan maupun reward bagi guru berprestasi, dan hendaknya kinerja guru perlu ditingkatkan lagi melalui kompetensi dan motivasi. Rekomendasi yang dapat diberikan yaitu kepala sekolah atau pun Dinas Pendidikan Kota Lubuklinggau perlu mempertimbangkan pengadaan kegiatan pelatihan ketrampilan dan pendidikan kompetensi 
Y.Susanto, JR.Riwukore, I.Afrianti, dan F.Habaora, Pengaruh Kompetensi dan....151

untuk guru-guru dalam rangka meningkatkan kinerja guru-guru, khususnya guru di SMP Negeri 4 Kota Lubuklinggau.

\section{Daftar Rujukan}

Afrilyan, B., Fitri, K., \& Mahardi. (2017). The effect of competence, work experience and job placement on organizational commitment PT. Wahana Meta Riau in Pekanbaru. JOM Fekon, 4(1), 153-166.

Aini, N. (2019). Evaluation of employee performance to realize public services from a good governance perspective. Jurnal Inovasi Ilmu Sosial dan Politik, 1(1), 43-57.

Danila, \& Riwukore, J. R. (2019). The influence of competence and motivation on employee performance in the Office of General Working of Bina Marga of South Sumatra Province. Jurnal Ecoment Global: Kajian Bisnis dan Manajemen, 4(2), 3951.

Daryanto, E. (2014). Individual characteristics, job characteristics, and career development: A study on vocational school teachers' satisfaction in Indonesia. American Journal of Educational Research, 2(8), 698-702.

Fathurrochman, I. (2017). Competency development of the State Civil Apparatus (ASN) of Islamic College employees (STAIN) through education and training methods. Jurnal Manajer Pendidikan, 11(21), 120-129.

Habaora, F. (2015). Populasi opini penyalahgunaan kekuasaan. Jogjakarta: Deepublish Press.

Habaora, F. (2020). Rekam jejak (2017-2019) dua tahun implementasi visi misi FirMan-mu di Kota Kupang "Ayo Berubah". Yogyakarta: Phoenix Publisher.

Hartono. (2019). Upaya meningkatkan motivasi dan kompetensi menyusun RPP cooperative learning model example non example melalui supervisi akademik bagi guru kelas di SD Negeri 02 Kedungjeruk Semester 1 Tahun Pelajaran 2019/2020. Jurnal Pendidikan, 28(3), 239-246.

Hasbi, M., \& Yusman. (2016). Kinerja guru Aqidah Akhlak, SKI, Al-Qur'an Hadits, Fiqih di Madrasah Tsanawiyah (MTs) Al-Ikhlas Keban II Kec. Sanga Desa, Kab. Muba. Jurnal of Islamic Education Management , 2 (2), 67-85.

Komara, E. (2019). Professional competencies of state civil apparatus' employee in Indonesia. Mimbar Pendidikan: Jurnal Indonesia Untuk Kajian Pendidikan, 4(1), 73-84.

Mahdane, A., Hubeis, M., \& Kuswanto, S. (2018). The influence of SKKNI and HR competencies on HR development in the HR Professional Unit in facing the MEA era. Jurnal Manajemen Pengembangan Industri Kecil Menengah, 13(1), 1-9.

Marlina, L. (2015 ). Manajemen sumber daya manusia (SDM) dalam pendidikan. Istinbath, $15(16), 123-139$.

Meirina, Y. (2013). The influence of job satisfaction, work environment and work motivation on employee performance in the Industrial and Energy Division of PT Haskoning Indonesia. MIX: Jurnal Ilmu Manajemen, 3(3), 322-332.

Novauli, M. F. (2015 ). Kompetensi guru dalam peningkatan prestasi belajar pada SMP Negeri Dalam Kota Banda Aceh. Jurnal Administrasi Pendidikan Pascasarjana Universitas Syiah Kuala, 3( 1 ), 45-67.

Riwukore, J. R. (2010). Effect of transformational leadership, competency motivation and commitment to work organization and performance of employees in Goverment 
Secretariat City Kupang, East Nusa Tenggara [Dissertation]. Surabaya: Programs Study of Economic Science, Postgraduate in Universitas 17 Agustus 1945.

Riwukore, J. R. (2020). Kepemimpinan transformasional peningkatan sumber daya manusia. Solok Sumatera Barat (Indonesia): CV. Insan Cendekia Mandiri.

Riwukore, J. R., \& Habaora, F. (2019). Perception of farmers on the performance of extensionist in the pasture agroecosystem of Timor Tengah Utara District. Asian Journal of Agricultural Extension, Economics \& Sociology, 29(2), 1-10.

Riwukore, J. R., \& Habaora, F. (2021). The influence of competence and work motivation to teacher performance in SMP Negeri at Kota Kupang. Ilkogretim Online Elementary Education Online, 20(1), 1010-1017.

Riwukore, J. R., Susanto, Y., Walyusman, Riance, A., Zubaidah, R. A., \& Habaora, F. (2021a). Analysis of employee performance based on competence and work climate in Lubuklinggau Barat I District at Indonesia. The Journal of Social Sciences Research, 7(1), 7-14.

Riwukore, J. R., Fuah, A. M., Abdullah, L., Priyanto, R., Yani, A., Purwanto, B. P., \& Habaora, F. (2021b). Profile of farmers based feed management and animal health of Bali cattle in agroecosystem variation at Timor Island. Bulletin of Animal Science, 45(2), 129-136.

Riyadi, S., \& Mulyaprada, A. (2017). Pengaruh motivasi kerja terhadap kinerja guru Radatul di Kota Pekalongan. Jurnal Litbang Kota Pekalongan, 13, 106-117.

Santoso, N. I. (2013). Pengaruh kepemimpinan kepala sekolah dan motivasi kerja terhadap kinerja guru SMK Budi Mulia Tangerang. MIX: Jurnal Ilmu Manajemen, 3(3), 272283.

Sugiyono. (2017). Methods of quantitative, qualitative and combination writing (mixed methods). Bandung, Indonesia: Alfa Beta Press.

Sujarweni, W. V. (2014). Methodology of research. Yogyakarta: Pustaka Baru Press.

Togatorop, J. B., \& Heryanto. (2019). The effect of teacher performance on student learning outcomes Public Elementary School 060934 Medan Johor Academic Year 2017/2018. International Journal of Education, Learning and Development, 7(5), 97-107.

Wibowo, S., Amboningtyas, D., Fathoni, A., \& Darsin. (2017). Analisis pengaruh kebutuhan fisiologis, kebutuhan keamanan, kebutuhan sosial, kebutuhan penghargaan, kebutuhan aktualisasi terhadap produktivitas kerja karyawan pada Fleet Departemen di PT. Serasi Autoraya Cabang Semarang. Journal of Management, 3(3), 1-10.

Wijaya, D. K. (2015). Pentingnya komunikasi organisasi, motivasi kerja dan kompetensi untuk meningkatkan kinerja guru. MIX: Jurnal Ilmu Manajemen, 6(2), 275-290.

Winbaktianur, \& Putri, N. U. (2017). The effectiveness of motivation training to increase the work motivation of outsourcing workers as cleaning service at UIN Imam Bonjol Padang. Konseli: Jurnal Bimbingan dan Konseling, 4(2), 65-80. 